\title{
Emergence of sandflies (Phlebotominae) in Austria, a Central European country
}

\author{
Wolfgang Poeppl • Adelheid G. Obwaller • Martin Weiler • Heinz Burgmann • \\ Gerhard Mooseder • Susanne Lorentz • Friedrich Rauchenwald • Horst Aspöck • \\ Julia Walochnik • Torsten J. Naucke
}

Received: 31 July 2013 / Accepted: 19 September 2013 /Published online: 15 October 2013

(C) Springer-Verlag Berlin Heidelberg 2013

\begin{abstract}
The possible existence of autochthonous sandfly populations in Central Europe north of the Alps has long been excluded. However, in the past years, sandflies have been documented in Germany, Belgium, and recently, also in Austria, close to the Slovenian border. Moreover, autochthonous human Leishmania and Phlebovirus infections have been reported in Central Europe, particularly in Germany. From
\end{abstract}

\author{
W. Poeppl $\cdot$ H. Burgmann \\ Department of Infectious Diseases and Tropical Medicine, \\ Medical University of Vienna, Vienna, Austria \\ W. Poeppl · G. Mooseder \\ Department of Dermatology and Tropical Medicine, \\ Military Hospital Vienna, Vienna, Austria \\ A. G. Obwaller \\ Division of Science, Research and Development, \\ Federal Ministry of Defence and Sports, Vienna, Austria \\ M. Weiler \\ Federal Ministry of Defence and Sports, Austrian \\ NBC-Defence-School, Korneuburg, Austria \\ S. Lorentz $\cdot$ T. J. Naucke \\ Parasitus Ex e.V., Niederkassel, Germany \\ F. Rauchenwald \\ Bayer Austria Ges.m.b.H., Vienna, Austria \\ H. Aspöck $\cdot$ J. Walochnik $(\triangle)$ \\ Institute of Specific Prophylaxis and Tropical Medicine, \\ Center for Pathophysiology, Infectiology and Immunology, Medical \\ University of Vienna, Kinderspitalgasse 15, 1090 Vienna, Austria \\ e-mail: julia.walochnik@meduniwien.ac.at \\ T. J. Naucke \\ Department of Zoology, Division of Parasitology, \\ University of Hohenheim, Stuttgart, Germany \\ T. J. Naucke \\ Laboklin GmbH \& Co. KG, Bad Kissingen, Germany
}

2010 to 2012, sandfly trapping (740 trap nights) was performed at 53 different capture sites in Austria using battery-operated CDC miniature light traps. Sites were chosen on the basis of their climate profile in the federal states Styria, Burgenland, and Lower Austria. Sandfly specimens found were transferred to $70 \%$ ethanol for conservation. Identification was based on morphological characters of the male genitalia and the female spermathecae, respectively. Altogether, 24 specimens, 22 females and 2 males, all identified as Phlebotomus (Transphlebotomus) mascittii Grassi, 1908, were found at six different sampling sites in all three federal states investigated. The highest number of catches was made on a farm in Lower Austria. Altogether, the period of sandfly activity in Austria was shown to be much longer than presumed, the earliest capture was made on July $3 \mathrm{rd}$ and the latest on August 28th. Sandflies have been autochthonous in Austria in small foci probably for long, but in the course of global warming, further spreading may be expected. Although $P$. mascittii is only an assumed vector of Leishmania spp.- data on its experimental transmission capacity are still lacking the wide distribution of sandflies in Austria, a country thought to be free of sandflies, further supports a potential emergence of sandflies in Central Europe. This is of medical relevance, not only with respect to the transmission of Leishmania spp. for which a reservoir is given in dogs, but also with respect to the phleboviruses.

\section{Introduction}

Sandflies (Diptera: Psychodidae: Phlebotominae) serve as vectors of various pathogens, including Leishmania spp., Bartonella spp. and phleboviruses. In Europe, sandflies are typical Mediterranean faunal elements which are widely distributed mainly in southern parts of Europe, but also in extraMediterranean regions in Eastern and Western Europe 
(Aspöck et al. 2008). The occurrence of sandflies in Central Europe north of the Alps has long been excluded. Then, in 1999, sandflies were recorded for the first time in the south-west of Germany (Naucke and Pesson 2000). In subsequent years, the autochthonous occurrence of sandflies in Central Europe was confirmed by further catches in Germany and Belgium. Recently, the occurrence of Phlebotomus (Transphlebotomus) mascittii was also documented in Austria, in Carinthia close to the border to Slovenia (Naucke et al. 2011). These recent sandfly catches together with autochthonous cases of leishmaniasis and Phlebovirus infections in Central Europe, particularly in Germany (e.g. Bogdan et al. 2001, Meyer-König et al. 2010), indicate spreading tendencies of the vectors within, as well as of sandfly-borne pathogens by anthropogenic influence towards Central Europe (Aspöck et al. 2008).

Aiming to investigate the possible occurrence of sandflies in isolated areas with favourable climatic conditions within regions previously considered free of sandflies, entomological field studies were performed in Southern and Eastern Austria.

\section{Materials and methods}

Austria is a landlocked, largely mountainous Central European country of $83,860 \mathrm{~km}^{2}$ located within the alpine arch. The lowlands and plains of the east and southeast, however, are part of the Vienna basin and the Pannoni low country with continental climate characterised by hot summers and cold winters. Austria is bordered by the Czech Republic and Germany to the north, Hungary and Slovakia to the east, Slovenia and Italy to the south, and Switzerland and Liechtenstein to the west, and is divided into nine federal states.

In July 2010, July and August 2011 and 2012, entomologic field studies were carried out in Southern and Eastern Austria to investigate the possible occurrence of sandflies. Batteryoperated CDC miniature light traps using fine gossamer collection bags (model \#512, John W. Hock Company, Gainseville, Florida) were run from dusk to dawn. Bags were collected daily in the morning and the contents were stored at $-20{ }^{\circ} \mathrm{C}$ until inspection. Sandfly specimens found were transferred to $70 \%$ ethanol for conservation. For species identification, sandflies were cleared in potassium hydroxide solution, and finally, slide-mounted in Hoyer's fluid (Naucke 1998). The sandflies were measured with a binocular Olympus CH-2 with the help of a camera lucida. The identification was based on morphological and morphometric parameters of males and females, particularly, the morphological characters of the male genitalia and of the female spermathecae, using the identification keys by Theodor (Theodor 1958) and Seccombe (Seccombe 1993).

Altogether, sandfly trapping was performed at 53 different capture sites with a total number of 740 trap nights. The sample sites were chosen on the basis of a risk profile on climatically most suited areas for the occurrence of sandflies in Austria (Aspöck et al. 2006). Oral informed consent for entomological sampling was obtained from all landowners and residents, respectively. All traps were installed at locations in the vicinity of human dwellings. The number of light traps and trap nights set at each location varied due to logistics and environmental factors and weather conditions.

In Styria, trapping was performed from July 12th to July 16th 2010 at 13 different trapping sites with a total number of 31 trap nights. Each site was examined for 1-2 nights, the number of traps used varied between 1-3 traps at each site.

In Burgenland, trapping was performed from July 18th to July 20th 2011 and for 17 nights between August 1st and August 26th 2011 at 32 different trapping sites with a total number of 203 trap nights. Each site was examined for 1-10 nights, the number of traps used varied between 2-6 traps at each site. The following year, sampling was repeated at one location with 6 traps run for 34 nights between July 2nd July and August 31st 2012 (204 trap nights).

In Lower Austria, trapping was performed at one trapping site with three traps for seven nights from August 16th to 19th and August 22nd to 26th 2011. The following year, sampling was repeated at this location with 8 traps run for 34 nights between July 3rd and August 31st 2012 (272 trap nights). An additional two traps were run on a second trapping site for 16 nights between July 3rd and July 23rd 2012.

Geographical data from trap sites were recorded with a global-positioning-system unit (Garmin, etrex VISTA HCx, USA). Temperature data on trapping regions were retrospectively obtained from the Central Institute for Meteorology and Geodynamics (ZAMG).

\section{Results}

Altogether, 24 sandfly specimens, all identified as Phlebotomus (Transphlebotomus) mascittii Grassi, 1908, were found at six different sampling sites in all three federal states investigated (Fig. 1). During the entire study period, the earliest capture was made on July 3rd and the latest on August 28th (Table 1).

In Styria, five females were found in Halbenrain $\left(46^{\circ} 43^{\prime} 21.18^{\prime \prime} \mathrm{N} / 15^{\circ} 56^{\prime} 30.96^{\prime \prime} \mathrm{E}\right.$ at 216 m.a.SL) during trapping for two nights (July 14th to 16th 2010) with three traps. The traps had been placed under a concrete stair of a mill and a wooden shed used for storage within a windless group of buildings. A further female was found in Pfarrsdorf $\left(46^{\circ} 42^{\prime} 27.84^{\prime \prime} \mathrm{N} / 15^{\circ} 57^{\prime} 51.12^{\prime \prime} \mathrm{E}\right.$ at 216 m.a.SL) during a trapping for two nights (July 14th to 16th 2010) with two traps. The traps had been installed in an open garage with concrete pavement near a human dwelling. Three females were captured on a third location in Ratzenau (46 $43^{\prime} 35.04^{\prime \prime}$ $\mathrm{N} / 15^{\circ} 49^{\prime} 4.26^{\prime \prime} \mathrm{E}$ at $233 \mathrm{~m}$.a.SL) during a trapping for two 


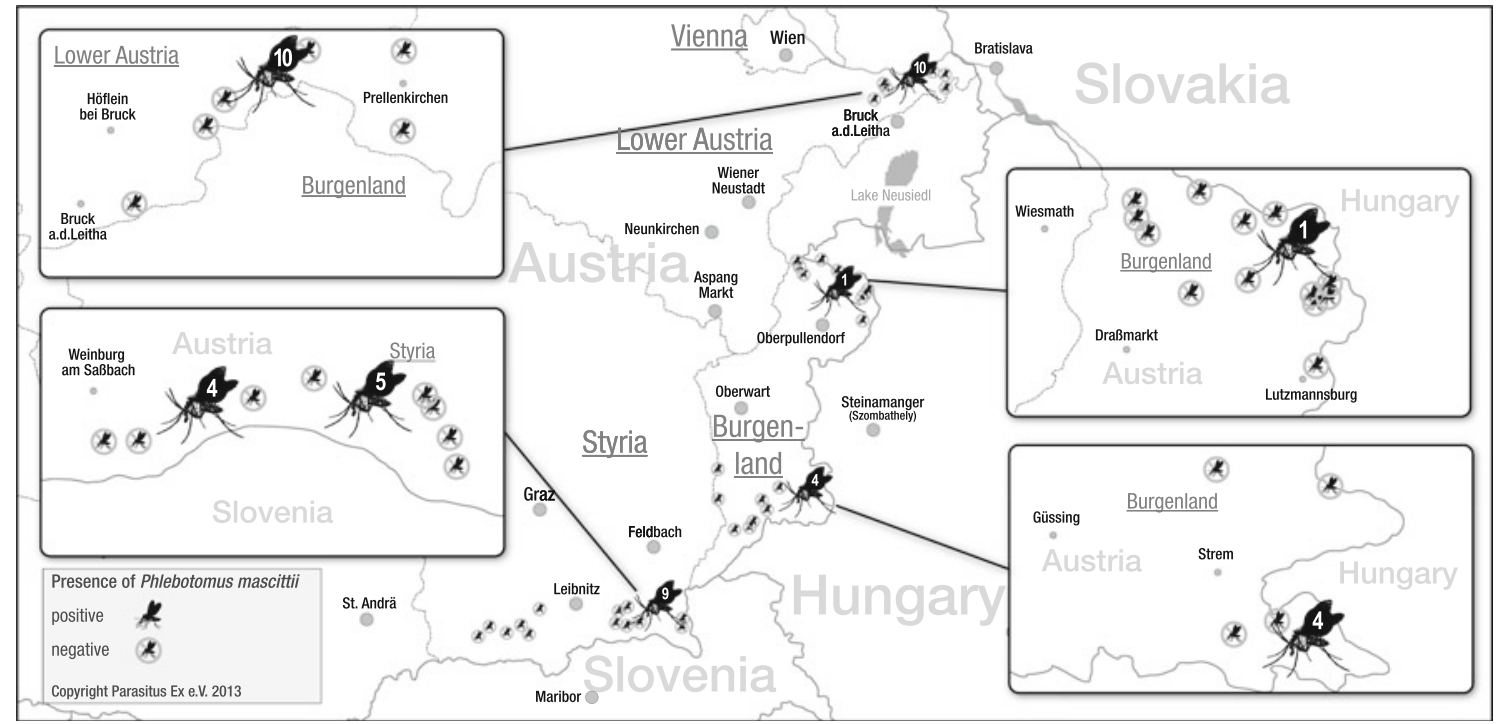

Fig. 1 Map showing capture sites in Styria, Burgenland and Lower Austria. Crosses indicate localities where no sandflies were found, the sandflies symbolise localities where Phlebotomus (Transphlebotomus) mascittii Grassi 1908, was detected. The numbers within the sandfly symbols represent the total number of catches made in this area, overlapping capture sites are not shown nights (July 14th to 16th 2010) with two traps. The traps were placed in a shed with loamy ground which was used as a lumber storage. In the area where those three villages with positive capture results are located, the mean monthly temperature in July 2010 was $18.9^{\circ} \mathrm{C}$ at 7 a.m., $26.9^{\circ} \mathrm{C}$ at 2 p.m. and $23.4^{\circ} \mathrm{C}$ at 7 p.m.

In Burgenland, one female was found in Deutschkreutz $\left(47^{\circ} 35^{\prime} 45^{\prime \prime} \mathrm{N} / 16^{\circ} 37^{\prime} 43.2^{\prime \prime} \mathrm{E}\right.$ at 196 m.a.SL) during trapping for a single night in August (August 2nd 2011) using three traps. The traps had been set up near human dwellings where no animals were kept. In the area of Deutschkreutz the mean monthly temperature in August 2011 was $18.5^{\circ} \mathrm{C}$ at 7 a.m., $25.9{ }^{\circ} \mathrm{C}$ at 2 p.m. and $21.8{ }^{\circ} \mathrm{C}$ at 7 p.m. Further sandflies, namely one female and one male were captured in Luising $\left(47^{\circ} 0^{\prime} 40.0^{\prime \prime} \mathrm{N} / 16^{\circ} 28^{\prime} 46.6^{\prime \prime} \mathrm{E} ; 47^{\circ} 0^{\prime} 45.9^{\prime \prime} \mathrm{N} / 16^{\circ} 28^{\prime} 50.2^{\prime \prime} \mathrm{E}\right.$ at 233 m.a.SL), where four traps had been in use from July 18th to 20th and August 2nd to 6th. One female and one male were captured on the 3rd and 19th of August 2011, respectively. The trap sites were located near a human dwelling in a wooden shed with little organic matter on the floor, in a barn with concreted floor used as a storage for equipment and straw bales and in an open garage with concrete pavement used for storage of agricultural equipment and wood. Close to the garage, chicken were kept. In the area of Luising, the mean monthly temperature in August 2011 was $17.5^{\circ} \mathrm{C}$ at 7 a.m., $26.8^{\circ} \mathrm{C}$ at 2 p.m. and $21.7^{\circ} \mathrm{C}$ at 7 p.m. In Luising, sandfly trapping was repeated 1 year later for 34 days between July 3rd and August 31 st 2012 using six traps. Two females were captured, one on July 24th, the other one on August 20th. The mean monthly temperature in this area was $19.4^{\circ} \mathrm{C}$ at 7 a.m., $27.7^{\circ} \mathrm{C}$ at 2 p.m. and $23.0^{\circ} \mathrm{C}$ at 7 p.m. in July 2012 , and $17.7^{\circ} \mathrm{C}$ at 7 a.m., $27.8^{\circ} \mathrm{C}$ at 2 p.m. and $23.2^{\circ} \mathrm{C}$ at 7 p.m. in August 2012.
In Lower Austria, three females were found in Rohrau $\left(48^{\circ} 3^{\prime} 56.664^{\prime \prime} \mathrm{N} / 16^{\circ} 51^{\prime} 33.084^{\prime \prime} \mathrm{E}\right.$ at 148 m.a.SL) during a trapping period of six nights in August 2011 (from July 18th to 20th and from August 2nd to 6th) using three traps. The traps had been located in a nineteenth century open wooden barn used for storage of bales and agricultural equipment, and in an open, concreted garage used for storage. A dog and several cats were held at this farm. In this area, the mean monthly temperature in August 2011 was $18.5^{\circ} \mathrm{C}$ at 7 a.m., $26.3{ }^{\circ} \mathrm{C}$ at 2 p.m. and $22.2^{\circ} \mathrm{C}$ at 7 p.m. In Rohrau, sandfly trapping was repeated in the year 2012 for 34 nights between the 3rd of July to the 31st of August using six traps. Six females and one male were captured between July 3rd and August 7th. A female and a male captured in Rohrau are shown in Figs. 2 and 3, respectively. The mean monthly temperature in this area was $19.5{ }^{\circ} \mathrm{C}$ at 7 a.m., $26.6{ }^{\circ} \mathrm{C}$ at 2 p.m. and $22.7^{\circ} \mathrm{C}$ at 7 p.m. in July 2012 and $19.2^{\circ} \mathrm{C}$ at 7 a.m., $26.9^{\circ} \mathrm{C}$ at 2 p.m. and $23.6^{\circ} \mathrm{C}$ at 7 p.m. in August 2012.

\section{Discussion}

Until the first and hitherto unique finding of sandflies in Austria near the Carinthian/Slovenian border in the year 2009 (Naucke et al. 2011), Austria was believed to be free of sandflies. However, it had already been shown that only a moderate increase in temperature would lead to conditions favourable for the occurrence of sandflies in large parts of the country (Aspöck et al. 2006). The expected species were $P$. mascittii in western parts of Austria and Phlebotomus neglectus in the east (Aspöck et al. 2006). A more recent study investigating the responses of sandfly vector species to climate change in Europe 


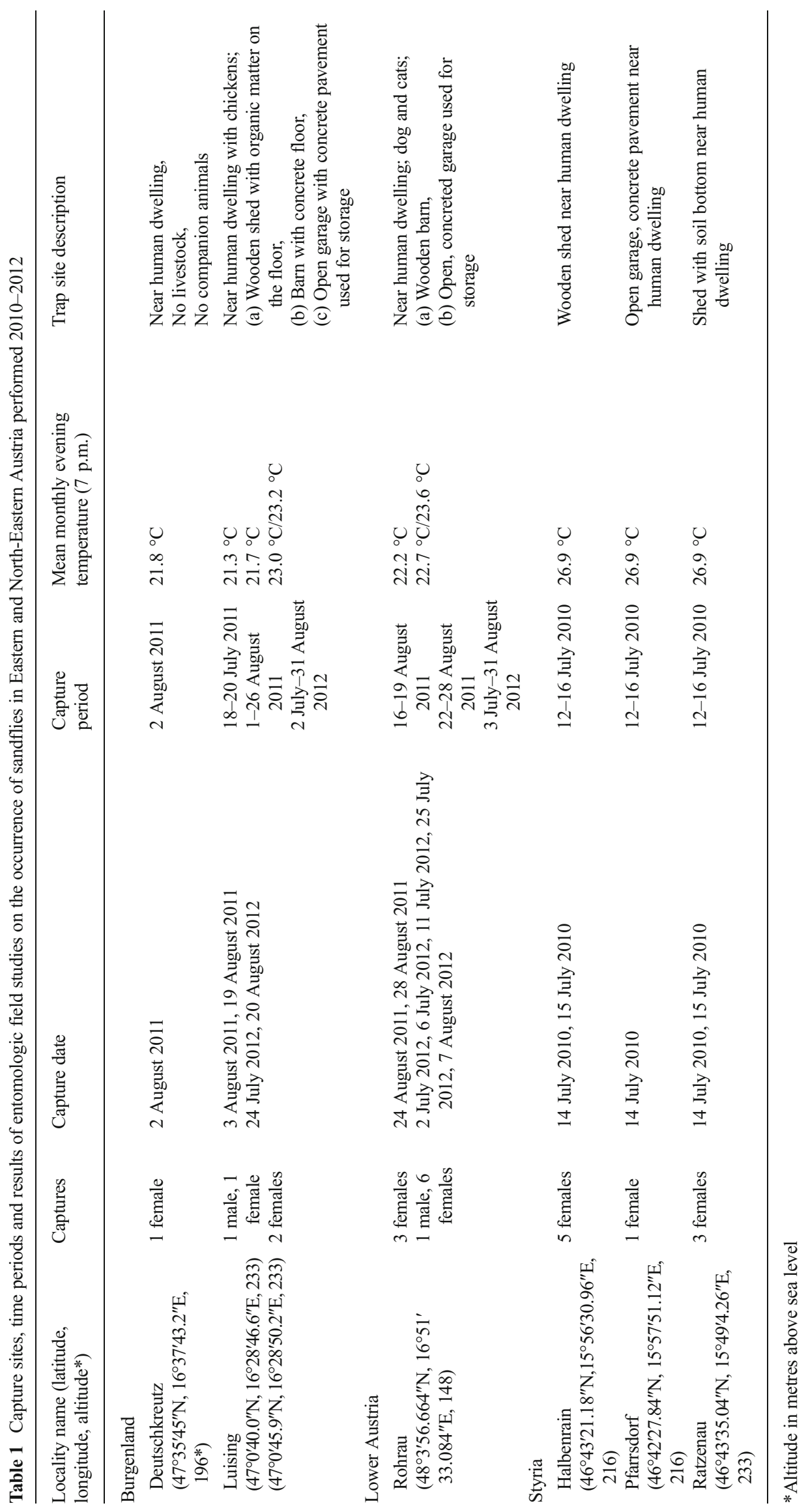




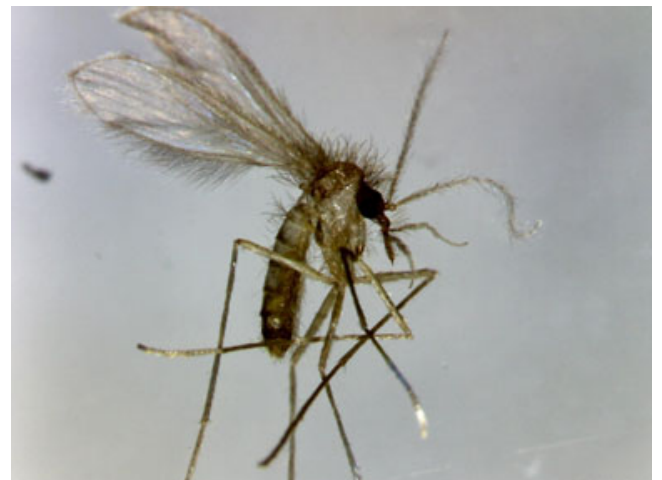

Fig. 2 A female of Phlebotomus (Transphlebotomus) mascittii captured in Rohrau, Lower Austria (Orig.)

by combining their dispersal abilities with climatic prospects, projected sandfly establishment of species with current southeastern focus ( $P$. neglectus, $P$. perfiliewi) in eastern Austrian regions neighbouring Slovenia and Hungary in the near future (Fischer et al. 2011). In that study it was further projected that $P$. ariasi and $P$. mascittii would disperse to south-eastern parts of Austria and would be able to occur in eastern and northeastern parts at the end of the twenty-first century (Fischer et al. 2011). Thus, it appears surprising that in the present study (1) $P$. mascittii and not $P$. neglectus was found in Eastern Austria and that (2) P. mascittii has obviously already established also in the north-eastern parts of Austria. However, the cited projections were based on the assumption that Austria was free of sandflies, and sandflies would invade the country from neighbouring countries. Today, all records of sandflies in Central Europe, including Austria, are considered to represent remnants of warmer periods in Central Europe and not to be associated with a recent immigration due to climate change and

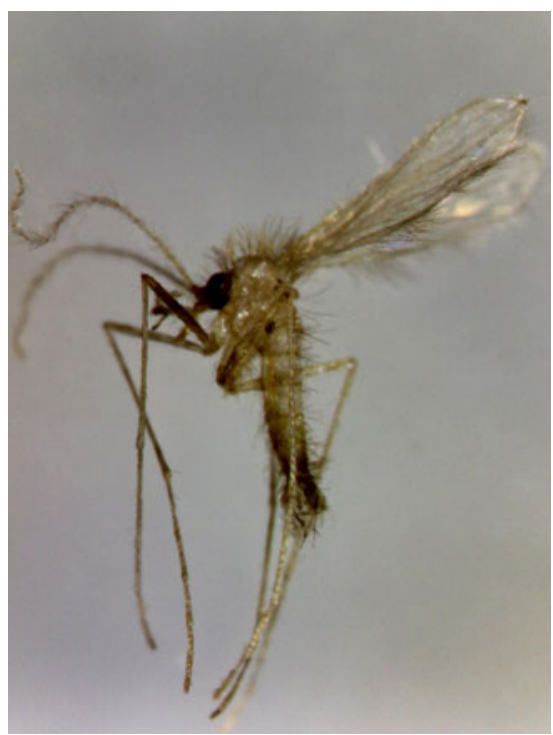

Fig. 3 A male of Phlebotomus (Transphlebotomus) mascittii captured in Rohrau, Lower Austria (Orig.) global warming (Aspöck 2010). Nevertheless, these findings might reflect a range expansion from small refugial areas and studies on climate change scenarios and dispersal abilities of sandfly species suggest that "the development of Central European climate will increasingly support suitable habitats for phlebotomine sandflies" (Fischer et al. 2011).

$P$. mascittii is widely distributed in the Mediterranean region from Spain in the West to Turkey in the East. North of the Alps, it has been found in France, Switzerland, Belgium, Germany (Aspöck et al. 2008), and recently in the South of Austria (Naucke et al. 2011). Considering the wide distribution, the presence of such remnants of the Holocenian optimum about 6,500 years ago in very localised spots in Austria is not surprising (Aspöck 2008; Aspöck 2010).

Based on the results of the present study, it can be concluded that sandflies are more widely distributed (and most probably have been for long) in Central Europe than previously realised. Sandflies were captured at 6 out of 44 trapping sites and in most areas trapping was performed only for a short period of time (in some areas even for only a single night). Thus, the present study provides clear evidence for the permanent occurrence of sandflies in those areas, but care should be taken when considering areas with negative capture results as sandfly-free. Nonetheless, the total number of sandfly catches made was rather low. Even at catching sites were sandfly trapping was performed over a period of several weeks, only a handful catches were made. In line with this, in several entomological studies, P. mascittii was found at low densities (Berdjane-Brouk et al. 2011; Maroli and Bettini 1977; Veronesi et al. 2007). Since the first description of $P$. mascittii in 1908 (Grassi 1908), not more than 20 P. mascittii were trapped each season (Raynal 1954). There is only one place known in Europe, where P. mascittii can be found in high numbers, and this is a 450-m long and blocked railway tunnel on the island of Corsica (Toumanoff and Chassignet 1954). Adult P. mascittii can be found all through the year inside this tunnel (Naucke et al. 2008b). In Germany, a 200year-old barn could be identified as a breeding place (Naucke 2002). Thus, to evaluate realistic population densities of $P$. mascittii, optimised catching methods are required. In a recent study from Northern Italy comparing sticky and sucking traps with or without light bait over a 4-month sampling period, only one out of 2,253 sandflies was identified as P. mascittii (Veronesi et al. 2007). Likewise, in an entomological study performed with CDC miniature light traps in Northern Algeria, only one individuals of $P$. mascittii was found among 883 sandflies (Berdjane-Brouk et al. 2011). However, because a sandfly species is probably not survivable in such a lowpopulation density, the number of catches made in the present study apparently does not reflect the real population density of $P$. mascittii in Austria. Our personal observation based on sandfly breeding experiences is that $P$. mascittii is less attracted by light in contrast to other sandfly species. Escaped 
sandflies in the laboratory rarely can be trapped in a CDC light trap, but often can be found on apple or peach pieces.

P. mascittii is an assumed vector of Leishmania spp., but data on its natural or experimental transmission capacity are still lacking. Nevertheless, in Germany, P. mascittii was found as the sole sandfly species in areas with at least most probable autochthonous Leishmania infections in humans and animals (Naucke 2002; Naucke et al. 2008a). And, as it is known, that the active dispersal capability of sandflies is very low (e.g. Rioux et al. 1979), it has to be assumed that in these cases, the causative Leishmania strains had been transmitted by $P$. mascittii. Also in Austria, two cases with assumed autochthonous Leishmania infections have been reported (Beyreder 1965; Kollaritsch et al. 1989). Interestingly, these were both from the eastern low parts of Austria, which is the part of Austria, where now sandflies were found and also where in a recent epidemiological study investigating asymptomatic Austrian adults, the highest seropositivity for Leishmania spp. was found (Poeppl et al. 2012).

When speculating on sandfly borne pathogens establishing in Austria, a prerequisite for autochthonous infections is not only the presence of a competent vector, but also of a pathogen reservoir. For Leishmania, dogs are certainly the most important reservoir hosts. In Mediterranean countries, Leishmania infections in dogs, and particularly in stray dogs, are very common (e.g. Brandonisio et al. 1992). Infected dogs usually develop conspicuous clinical symptoms leading to a miserable appearance, so that many infected stray dogs have been brought home by compassionate German and Austrian tourists. This has meanwhile even led to such dogs being offered for sale via the internet. According to conservative estimates about 20,000 dogs infected with Leishmania presently live in Germany (Naucke et al. 2008a). In dogs, therapy is usually more complicated than in humans, moreover, dogs are assumed to remain reservoirs even after successful therapy, and also asymptomatic dogs can pass on the infection to sandflies (Alvar et al. 2004, Ashford et al. 1998). Also in Austria, the percentage of infected dogs seems to be high, although until now, the number of dogs that have been investigated for Leishmania infection is still rather low (Edelhofer et al. 1995; Leschnik et al. 2008). But also horses, cats and other domestic animals are transported within and imported into Europe, and also these animals may play a role as reservoir hosts (Englund and Pringle 2003). Moreover, a Leishmania focus can be maintained by circulation of the parasites between sandflies and rodents.

The period of sandfly activity in Austria was shown to be rather long, long enough to allow Leishmania parasites to complete their life cycle in the vectors and following transmission to vertebrate hosts. Although at most sampling sites, traps were run for only a few days, sandflies were caught from early July to late August. Rising temperatures, particularly in summer, may lead to growing populations of autochthonous sandfly species and also favour the introduction of other sandfly species.

Sandflies can also transmit other pathogens, particularly phleboviruses, which have to be kept in mind, because they are wide-spread in Southern Europe and a sandfly that might lack vector capability for Leishmania spp. may still be a potent vector for various phleboviruses. Autochthonous human infections with phleboviruses have recently occurred in Southern Germany (Meyer-König et al. 2010).

In conclusion, it was shown that sandflies are much more widely distributed in Austria than previously assumed, currently in small foci, but in the course of global warming, further spreading may be expected. This is of potential medical relevance, not only with respect to transmission of Leishmania spp., for which a reservoir is known to exist in Austria, but also of other pathogens, in particular phleboviruses.

Acknowledgments The authors thank Colonel Georg Rosenmayr, MD, for his expert support as well as Johann Trinkl, Andreas Mangold, Warrent Officer II Stefan Müller and Staff Sergeant Christian Kittelmann of the Military Command Burgenland for excellent technical assistance. We further thank the Central Institute for Meteorology and Geodynamics (ZAMG) for their kind cooperation.

Funding The study was supported by the Austrian Federal Ministry of Defence and Sports, the Medical University of Vienna, Austria, and Bayer Austria. The funders had no role in the study design, data collection and analysis, decision to publish, or preparation of the manuscript.

Competing interests The authors declare that they have no competing interests.

\section{References}

Alvar J, Canavate C, Molina R, Moreno J, Nieto J (2004) Canine leishmaniasis. Adv Parasitol 57:1-88

Ashford DA, David JR, Freire M, David R, Sherlock I, Eulalio MD, Sampaio DP, Badaro R (1998) Studies on control of visceral leishmaniasis: impact of $\operatorname{dog}$ control on canine and human visceral leishmaniasis in Jacobina, Bahia, Brazil. Am J Trop Med Hyg 59:53-57

Aspöck H (2008) Postglacial formation and fluctuations of the biodiversity of Central Europe in the light of climate change. Parasitol Res 103(Suppl 1):S7-S10

Aspöck H (2010) Fluctuations of Biodiversity in Europe in Light of Climate Change. In: B. Friedrich, J. Hacker, S. E. Hasnain, Th. C. Mettenleiter \& J. Schell (Eds.): Climate Change and Infectious Diseases. Nova Acta Leopoldina NF 111, Nr. 381:35-44

Aspöck H, Walochnik J, Gerersdorfer T, Formayer H (2006) Risiko-Profil für das autochthone Auftreten von Leishmaniosen in Österrreich. StartClim2006B. URL: http://www.austroclim.at/startclim: pp. 49

Aspöck H, Gerersdorfer T, Formayer H, Walochnik J (2008) Sandflies and sandfly-borne infections of humans in Central Europe in the light of climate change. Wien Klin Wochenschr 120(Suppl 4):24-29

Berdjane-Brouk Z, Charrel RN, Bitam I, Hamrioui B, Izri A (2011) Record of Phlebotomus (Transphlebotomus) mascittii Grassi, 1908 and Phlebotomus (Larroussius) chadlii Rioux, Juminer \& Gibily, 1966 female in Algeria. Parasite 18:337-339 
Beyreder J (1965) A case of leishmaniasis in Lower Austria. Wien Med Wochenschr 115:900-901

Bogdan C, Schönian G, Bañuls AL, Hide M, Pratlong F, Lorez E, Röllinghoff M, Mertens R (2001) Visceral leishmaniasis in a German child who had never entered a known endemic area: case report and review of the literature. Clin Infect Dis 32:302-306

Brandonisio O, Carelli G, Ceci L, Consenti B, Fasanella A, Puccini V (1992) Canine Leishmaniasis in the Gargano promontory (Apulia, South Italy). Eur J Epidemiol 8:273-276

Edelhofer R, Kosztolich A, Mitterhuber C, Kutzer E (1995) Imported cases of Leishmaniasis in dogs, a retrospective study concerning Austria (1985-1994). Wien Tierarztl Monatsschr 82:90-95

Englund L, Pringle J (2003) New diseases and increased risk of diseases in companion animals and horses due to transport. Acta Vet Scand Suppl 2003-2004(100):19-25

Fischer D, Moeller P, Thomas SM, Naucke TJ, Beierkuhnlein C (2011) Combining climatic projections and dispersal ability: a method for estimating the responses of sandfly vector species to climate change. PLoS Negl Trop Dis 5:e1407. doi:10.1371/journal.pntd.0001407

Grassi GB (1908) Intorno ad un Nuevo flebotomo. Atti della R Accad dei Lincei Rend 5:681-682

Kollaritsch H, Emminger W, Zaunschirm A, Aspock H (1989) Suspected autochthonous kala-azar in Austria. Lancet 1(8643):901-902

Leschnik M, Lowenstein M, Edelhofer R, Kirtz G (2008) Imported nonendemic, arthropod-borne and parasitic infectious diseases in Austrian dogs. Wien Klin Wochenschr 120(Suppl 4):59-62

Maroli M, Bettini S (1977) Leishmaniasis in Tuscany (Italy): (I) An investigation on phlebotomine sandflies in Grosseto Province. Trans R Soc Trop Med Hyg 71:315-321

Meyer-König U, Schneider S, Özdemir S, Hutmacher K, Weidmann M, Kaiser R, Rauer S, Dobler G, Hufert FT (2010) Toscana virusassociated encephalitis is emerging north of the Alps. In: National Symposium on Zoonoses Research 2010. Berlin, Germany

Naucke TJ (1998) Untersuchungen zur Vektorkontrolle von Sandmücken in Nordostgriechenland. - Doctoral thesis in Natural Science, University of Bonn. S. Roderer Verlag, Regensburg:1-205. ISBN $3-$ 89783-017-5
Naucke TJ (2002) Leishmaniose, eine Tropenkrankheit und deren Vektoren (Diptera, Pyschodidae, Phlebotominae) in Mitteleuropa. In: H. Aspöck (Hrsg.): Amöben, Bandwürmer, Zecken, Parasiten und parasitäre Erkrankungen des Menschen in Mitteleuropa. Denisia 6:163-178

Naucke TJ, Pesson B (2000) Presence of Phlebotomus (Transphlebotomus) mascittii Grassi, 1908 (Diptera : Psychodidae) in Germany. Parasitol Res 86:335-336

Naucke TJ, Menn B, Massberg D, Lorentz S (2008a) Sandflies and leishmaniasis in Germany. Parasitol Res 103(Suppl 1):S65-S68

Naucke TJ, Menn B, Massberg D, Lorentz S (2008b) Winter activity of Phlebotomus (Transphlebotomus) mascittii, Grassi 1908 (Diptera: Psychodidae) on the island of Corsica. Parasitol Res 103:477-479

Naucke TJ, Lorentz S, Rauchenwald F, Aspock H (2011) Phlebotomus (Transphlebotomus) mascittii Grassi, 1908, in Carinthia: first record of the occurrence of sandflies in Austria (Diptera: Psychodidae: Phlebotominae). Parasitol Res 109:1161-1164

Poeppl W, Herkner H, Tobudic S, Faas A, Auer H, Mooseder G, Burgmann H, Walochnik J (2012) Seroprevalence and asymptomatic carriage of Leishmania spp. in Austria, a non-endemic European country. Clin Microbiol Infect 19:572-577

Raynal J (1954) Les phlébotomes de France et leur distribution régionale. Ann Parasitol Hum Comp 29:297-323

Rioux JA, Killick-Kendrick R, Leaney AJ, Turner DP, Bailly M, Young CJ (1979) Ecology of leishmaniasis in the south of France. - 12. Horizontal dispersion of Phlebotomus ariasi Tonnoir, 1921. Preliminary experiments (author's transl). Ann Parasitol Hum Comp 54(6): 673-682

Seccombe A, Ready PD, Huddleston LM (1993) A catalogue of old world phlebotomine sandflies (Diptera: Psychodidae, Phlebotominae). Occasional Papers on Systematic Entomology, Natural History Museum, London, pp 1-57

Theodor O (1958) Psychodidae - Phlebotominae. Schweizerbart'sche Verlagsbuchhandlung, Stuttgart

Toumanoff C, Chassignet R (1954) Contribution a l'étude des phlébotomes en Corse. Bull l'Institut Natl d'Hygiène 9:664-687

Veronesi E, Pilani R, Carrieri M, Bellini R (2007) Trapping sand flies (Diptera: Psychodidae) in the Emilia-Romagna region of northern Italy. J Vector Ecol 32:313-318 